Vol. 6 №. 1, Mei 2019 (pp. 55-69)

ISSN : 2580-6181 (Print), 2599-2481 (Onl ine)

Available online at:

http://e journal. upi. edu/index. php/tarbawy/index

\title{
PEMIKIRAN TAN MALAKA DAN RELEVANSINYA DENGAN PENDIDIKAN ISLAM
}

\author{
M. Maulana Rokhim,* \\ Munawar Rahmat, Cucu Surahman
}

Universitas Pendidikan Indonesia (UPI), Indonesia

*E-mail:maulana.ipai.upi@gmail.com

\begin{abstract}
Indonesian philosophy-based education is one way to face an era full of global competition. It is Ibrabim Datuk Tan Malaka, a revolutionary Indonesian independence movement who has the concept of education based on the people. This study aims to find out about Tan Malaka's educational thinking, especially with regard to the basis, objectives, principles, material, methods and evaluation of education and its relevance to Islamic education. This research was conducted with a qualitative approach. The method used is descriptive analysis. To trace the history of Tan Malaka's thought, a historical search method is used to find the purpose of Tan Malaka's educational concepts with data collection techniques in the form of literature studies and library research. Based on the results of this research, it is concluded that education according to Tan Malaka is an attempt to free people from misery, oppression, and ignorance, making life more useful for themselves and their surroundings, no more caste and class differences. The relevance of Tan Malaka's educational thought to Islamic education is found in his philosophy, bases, and objectives of education.
\end{abstract}

Keywords: Education, Tan Malaka, Relevance

Abstrak. Pendidikan yang berbasis falsafah bangsa Indonesia merupakan salab satu cara menghadapi era yang penuh persaingan global. Adalah Ibrabim Datuk Tan Malaka seorang revolusioner pergerakan kemerdekaan Indonesia yang memiliki konsep pendidikan yang berbasis pada rakyat. Penelitian ini bertujuan mengetabui pemikiran pendidikan Tan Malaka, khususnya yang berkenaan dengan dasar, tujuan, prinsip, materi, metode dan evaluasi pendidikan serta relevansinya dengan pendidikan Islam. Penelitian ini dilaksanakan dengan pendekatan kualitatif. Adapun metode yang digunakan adalab deskriptif-analisis. Untuk mencari jejak sejarab pemikiran Tan Malaka, metode penelusuran sejarah digunakan untuk menemukan maksud dari konsep pendidikan Tan Malaka dengan teknik pengumpulan data berupa studi literatur dan library research. Berdasarkan basil penelitian ini diperoleh gambaran babwa pendidikan menurut Tan Malaka adalah sebuah usaha untuk membebaskan manusia dari kesengsaraan, ketertindasan, dan ketidaktabuan, menjadikan bidup lebih bermanfaat bagi diri sendiri dan sekitarnya, tidak ada lagi kasta dan perbedaan kelas-kelas. Adapun Relevansi pemikiran pendidikan Tan Malaka dengan pendidikan Islam terdapat pada tinjauan filosofis, dasar, dan tujuan pendidikan.

Kata Kunci: Pendidikan, Tan Malaka, Relevansi 


\section{PENDAHULUAN}

Pendidikan yang berbasis falsafah bangsa Indonesia adalah salah satu cara dalam menghadapi era yang penuh persaingan global sehingga dapat terjaga nilai-nilai kebudayaan bangsa Indonesia. Menurut Muhammad Natsir maju-mundurnya sebuah negara tergantung dari pendidikan. Tegasnya sebuah negara bisa saja maju dan berkembang ketika dilakukan pembenahan dan perbaikan dalam hal pendidikan (Alimin, 1973, hal. 77).

Menurut Dzulfikriddin, bagi Natsir, pendidikan adalah bagian yang integral dari kehidupan, dan kehidupan itu sendiri adalah proses pendidikan sepanjang hayat (Dzulfikriddin, 2010, hal. 22). Senada dengan itu, menurut Waini Rosyidin, dkk. (2013, hal. 27) pendidikan adalah hidup, pendidikan adalah segala pengalaman belajar yang berlangsung dalam segala lingkungan dan sepanjang hidup, pendidikan adalah segala situasi hidup yang mempengaruhi pertumbuhan individu.

Dalam sabda Rasulullah Saw:

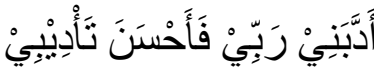

Tubanku mendidikku dengan sebaikbaiknya, maka sunggub baik hasil pendidikanku (HR. Ibn Sam'ani) (Jalaluddin, 2003, bal. 73)

Hadis tersebut mengisyaratkan bahwa Allah adalah sebaik-baiknya Pendidik, dan Allah telah mendidik Rasulullah dengan sebaik-baiknya pendidikan. Maka sungguh tidak diragukan kembali bahwa Alquran merupakan sumber pendidikan yang hakiki bagi setiap umat muslim di dunia.
J.J Rousseau (Gandhi, 2011, hal. 65) mendefinisikan pendidikan sebagai pemberian bekal kepada masyarakat di masa depan. Pendidikan sebagai social capital yang akan menggerakkan roda pembangunan harus dipandang sebagai kebutuhan pokok. Namun pendidikan yang diberikan jangan mengabaikan prinsip-prinsip karakter bangsa dan humanisme. Implikasi atas cara pandang, kultur dan pola berpikir yang hanya membenarkan kenyataan empiris sangat mempengaruhi dan menentukan sistem pendidikan yang dikembangkan; sebuah sistem pendidikan yang hanya mengacu pada paradigma liberalisme. Dengan begitu, maka lahirlah sebuah generasi yang mengagungkan kebebasan, lepas dari dataran etis, norma dan agama.

Asy'ari berpendapat bahwa "kemerdekaan dan pendidikan" di Indonesia belum benar merdeka karena ilmu pengetahuan yang diajarkan tidak dapat membebaskan peserta didiknya menjadi manusia yang mandiri secara sosial dan ekonomi. Sebaliknya justru terperangkap dalam neo-feodalism dengan mengejar gelar tanpa isi keilmuan aktual (Asy'ari, 2004, hal. 1). Senada dengan Asy'ari dan Al-Jamil, menurut Karim (2009, hal. 20), banyak lembaga pendidikan di Indonesia yang menggunakan Barat sebagai acuan pokok tanpa melakukan filterisasi terlebih dahulu.

Dengan demikian perlu adanya konsep pendidikan yang didasarkan pada realitas. Karena pendidikan harus mampu menyerap realitas dan menjadi jawaban atas realitas itu sendiri. Pendidikan harus dapat mengembangkan kreatifitas peserta didik untuk menghadapi tantangan perubahan hidup. 
Pendidikan memang selayaknya harus dapat mengembangkan kreatifitas peserta didiknya, agar kelak mereka mampu mandiri dengan cara mengembangkan potensi diri yang dimilikinya (Asy'ari, 2004, hal. 1).

Berbicara pendidikan kritis, emansipatoris, dan berciri khas kebangsaan, di Indfonesia ini terdapat tokoh yaitu Ibrahim Datuk Tan Malaka (selanjutnya disebut Tan Malaka). Ia merupakan seorang pejuang revolusioner yang tidak hanya memahami filsafat dan teori-teori pendidikan, namun terlibat aktif dalam memperjuangkan pendidikan sebagai media penyadaran pembebasan dari penindasan kolonialisme. Pemikiran tentang pendidikannya tertuang dalam brosur "SI Semarang dan Onderwijs" (Suwarto, 1999).

Tan Malaka ingin berusaha mewujudkan pendidikan yang mendahulukan kearifan lokal, agar masyarakat memperoleh bekal bagi penghidupannya. Oleh karena itu pendidikan kejuruan seperti: pertanian, perdagangan, teknik, dan administrasi harus dibenahi kualitasnya. Pendidikan praksis Tan Malaka diwujudkannya di sekolah Sarekat Islam (SI).

Dengan demikian dalam artikel ini penulis mencoba untuk menggali ide-ide Pendidikan Tan Malaka dan Relevansinya dengan Pendidikan Islam.

\section{METODE PENELITIAN}

Dalam penyusunan karya ilmiah ini, karena penelitian ini dikategorikan ke dalam penelitian kualitatif maka yang menjadi instrument dalam penelitian ini adalah penulis itu sendiri. Satori \& Komariah (2014, hal. 61) menjelaskan bahwa peneliti dalam penelitian kualitatif disebut key instrument (instrumen kunci) karena peneliti merupakan orang yang membuka kunci, menelaah, dan mengeksplorasi seluruh ruang secara cermat, tertib dan leluasa.

Teknik pengumpulan data yang digunakan untuk menyusun laporan karya ilmiah ini adalah studi kepustakaan (library research), yaitu mencari data yang berkaitan dengan pembahasan. Data yang terhimpun kemudian dianalisis sehingga dapat dijadikan sumber rujukan. Darwis (2014, hal. 32) menjelaskan bahwa kegiatan studi kepustakaan pada prinsipnya adalah sangat positif, baik bagi peneliti maupun bagi orang lain yang tertarik terhadap penelitian. Jika kegiatan ini dilaksanakan secara teliti dan intensif dengan logika dan cara yang benar, maka peneliti akan dapat menambah dimensi baru dalam kerangka berfikir.

Objek penelitian ini mengenai pemikiran pendidikan Tan Malaka, yang digali dari sumber data primer, yaitu buku SI Semarang dan Onderwijs, Madilog : Materialisme, Dialektika, Logika, dan Naar de Republiek Indonesia.

Sumber lain yang menjadi pertimbangan tambahan dalam mengadakan penelitian ini adalah bukubuku yang membahas mengenai pemikiran Pendidikan Tan Malaka. Penelitian ini disertai dengan menganalisis relevansinya dengan Pendidikan Islam, dari tinjauan filsafat, dasar dan tujuan pendidikan. 


\section{HASIL PENELITIAN DAN PEMBAHASAN}

\section{a. Konsep Pendidikan Menurut Tan Malaka}

\section{Pengertian Pendidikan}

Tan Malaka berpendapat bahwa pendidikan adalah sebuah usaha untuk membebaskan manusia dari kesengsaraan, ketertindasan, dan ketidaktahuan, menjadikan hidup lebih bermanfaat bagi diri sendiri dan sekitarnya, tidak ada lagi kasta dan pembeda kelas-kelas. Hal ini sejalan dengan pendapat Ahmad Tafsir bahwa pendidikan adalah bimbingan atau pimpinan secara sadar oleh pendidik terhadap perkembangan jasmani dan ruhani anak didik menuju terbentuknya kepribadian yang utama (Tafsir, 2012, hal. 34). Lebih dalam Tan Malaka mengungkapkan bahwa pendidikan merupakan sebuah usaha yang dapat membebaskan masyarakat dari kebodohan, lemah dan terlemahkan serta ketertindasan yang tiada ujung.

\section{Dasar Pendidikan}

Dasar yang dipakai Tan Malaka dalam pendidikannya ialah didasarkan pada ideologi Materialisme. Walaupun dasar yang dipakai Tan Malaka adalah materialisme, namun materialisme yang Tan Malaka maksud adalah mengajak pada anti-mistifikasi, dengan meyakini hasil kerja sebagai proses dari sebuah berubahan. Dua ideologi yang memengaruhi mindset dan worldview Tan Malaka adalah filsafat Hegelian dan Karl Marx. Pengaruh filsafat Hegelian tampak dalam konstruksi pemikiran Tan Malaka yang mengadopsi siklus thesis-antithesis dan synthesis. Sementara itu pengaruh Marx dalam bentuk sosialismekomunisme tampak dalam perspektif materialisme historis, fase perkembangan masyarakat, dan pertentangan antar kelas serta jalan revolusioner yang dianut Tan Malaka. Pengaruh dari dua pemikiran tersebut tampak dari world view, pemahamannya terhadap sejarah serta ciri-ciri pada alat analisis, argumentasi dan retorika yang ditemukan dalam tulisan-tulisan Tan Malaka (Abidin, 2016, hal. 5).

Keadaan Internasional, Minangkabau dan Alam Pikiran Barat juga berpengaruh pada latar belakang pemikiranya, walaupun Tan Malaka sedikit banyak dipengaruhi oleh filsafat Hegelian yang tampak dalam konstruksi pemikirannya. Namun sumber kehidupan yang dipakai Tan Malaka adalah Agama Islam sebagaimana penuturanya yang tertuang dalam buku Islam dalam Madilog sebagai berikut.

“...Sumber yang saya peroleb dari agama Islam inilah sumber yang hidup dalam diri saya.... Meskipun berbagai angin taufan pengarub dari derasnya pemikiran dan berbagai kejadian di Eropa mengaduk-aduk, menyeret sampai menghilirkan saya ke peristiwa 1917, minat saya terbadap Islam terus hidup.... Kejiwaannya masib tersimpan dalam subconscious...,"(Malaka, 2014, hal. 13-14).

Dengan demikian dapat disimpulkan bahwa Tan Malaka merupakan sosok yang konsekwen dengan apa yang diyakininya, dan tidak mudah terpengaruh dengan pemikiran Barat yang mengaduk-aduk bahkan menyeretnyeret pemikiranya. Agama Islam masih tetap terpatri dalam jiwanya dan terus hidup. Dengan demikian, dapat 
diinterpretasikan bahwa sumber yang dipakai Tan Malaka untuk pendidikannya sedikit banyak berasal dari Agama Islam.

\section{Tujuan Pendidikan}

Dalam brosur kecil S.I Semarang dan Onderwijs Tan Malaka menguraikan dasar dan tujuan sekolah Sarikat Islam (SI) serta cara mencapai tujuan pendidikanya.

Tujuan sekolah S.I. bukanlah mendidike murid menjadi juru tulis seperti tujuan Sekolah Gubernemen (sekolah kolonial), melainkan untuk mencari nafkah diri sendiri, keluarganya, dan membantu pergerakan rakyat (Malaka, 2011, hal. 4).

Untuk merumuskan tujuan pendidikanya Tan Malaka menyesuaikan dengan realitas atau kebutuhan masyarakat pada waktu itu, yaitu (1). Memberi keterampilan, (2). Memberi keleluasaan terhadap potensi belajarnya, termasuk kesukaan hidup (hobi), dengan jalan bergaul atau berkumpul, (3). Menanamkan rasa peduli dan tolong menolong terhadap sesamanya.

Dari ketiga tujuan ini menunjuk-kan bahwa tujuan pendidikan Tan Malaka berjalan secara sistematik dengan memberikan pembekalan pada aspek kognitif, afektif dan kemudian menuju ke arah pembentukan pemimpin yang memiliki virtue atau kebajikan yang berpihak pada rakyat kecil. Sebagai usaha besar untuk mencapai Indonesia Merdeka (Malaka, 2011, hal. 22).

Menurut Tan Malaka sebagaimana yang dikutip oleh Abidin (2016, hal. 6), peluang mengenyam pendidikan pada zaman kapitalistik semata-mata dilandaskan pada sentimen ras dan kepemilikan materi serta tidak memandang potensi peserta didik, khususnya yang berasal dari masyarakat proletar. Hasil dari pendidikan semacam itu adalah lahirnya manusia inlanders atau alat yang berpihak pada penguasa kolonial dan menindas kaum kromo. Yang kemudian Tan Malaka mendobrak sistem pendidikan semacam itu dengan mendesain pendidikan non-profit, terjangkau dan bersumber dari swadaya masyarakat. Dengan demikian, kaum kromo yang berpotensi namun berpenghasilan rendah dapat mengenyam pendidikan setara dengan Governement School.

Penjelasan dari tujuan pendidikan Tan Malaka dapat diuraikan di bawah ini.

1) Memberi senjata cukup, buat pencarian penghidupan dalam dunia kemodalan (berhitung, menulis, ilmu bumi, bahasa Belanda, Jawa, dan Melayu)

Pengembangan pengetahuan kognitif yang bertujuan untuk pembekalan keahlian dan kepandaian dalam menghadapi kehidupan sehari-hari serta secara bertahap membangun konstruksi pemikiran kritis untuk melawan hegemoni dan diskriminasi yang berlangsung dalam masyarakat. Dalam tujuan pendidikan tersebut, pembelajaran yang dilakukan harus memberikan ilmu yang bermanfaat bagi kehidupan dan kebutuhan sehari-hari masyarakat, tidak hanya menajamkan kercedasan otak tetapi juga ilmu yang berhubungan dengan olah fisik dan keahlian pekerjaan tangan (Abidin, 2016, hal. 7). 
Tan Malaka berkata "Nyata buat kita yang anak-anak suka bekerja keras untuk mencari kepandaian, yang perlu kelak buat keperluan hidup (seperti membaca, menulis, berhitung, bahasa dsb) pada dunia kemodalan, yang tiada memberi kasihan satu sama lain... Itu memang kewajiban kita sebagai gurunya, supaya kelak anak-anak yang keluar dari sekolah SI cukup membawa senjata unuk perjuangan kelak dalam hal mencari pakaian dan makanan buat anak istrinya"(Malaka, 2011, hal. 21).

2) Memberi hak murid-murid dalam kehidupan sosial, dengan jalan pergaulan (verenigging), dan membangun iklim kolektivitas dalam pendidikan dan pembelajaran.

Tan Malaka mengingingkan pendidikan tanpa kelas yang pada suatu saat nanti akan melahirkan masyarakat tanpa kelas. Untuk itu, sekolah bagaikan laboratorium sosial yang membelajarkan peserta didik untuk hidup bersosial tanpa stratifikasi serta membangun kolektivitas peserta didik untuk berkecimpung dalam dunia kemodalan.

Tan Malaka mengungkapkan spirit pendidikan kolektivitas tersebut dalam Keterangan Ringkas dalam Program Maksimum tahun 1948 (Abidin, 2016, hal. 7). Lanjut menurut Tan Malaka, Kemakmuran yang setinggi-tingginya dapat diperoleh cuma dengan jalan mekanisasi (pemakaian mesin semodern- modernnya). Pemakaian mesin yang paling efisien cuma dapat diperoleh dengan kerja gotongroyong yang teratur rapi (kolektifisasi) (Malaka, 2014, hal. $50)$.

Secara teoretik, model sosiokonstruktivistik semacam itu memuat aktivitas scaffolding yang memiliki kedudukan strategis dalam proses pembelajaran. Peserta didik yang lebih tua akan menjadi guru dan membimbing peserta didik yang lebih muda. Proses pembelajaran semacam itu merupakan membangun kesadaran collective networking dan menjadi bagian dari konstruksi kolektivitas yang dibangun oleh Tan Malaka (Abidin, 2016, hal. 8).

3) Menunjukkan kewajiban kelak, terhadap berjuta-juta Kaum Kromo (rakyat kecil).

Pendidikan melahirkan agenagen perubahan yang tak terkungkung kesadaran palsu. Sehingga mampu memimpin dan mengubah sistem dan struktur masyarakat. Dalam imaji Tan Malaka, pendidikan menyiapkan agen-agen tersebut secara berkesinambungan dan jangka panjang (Abidin, 2016, hal. 8).

Dengan demikian, menurut Tan Malaka pendidikan tidak dapat dipisahkan dari mempelajari hakekat realita yang merupakan pusat dari setiap konsep pendidikan. Pentingnya hal tersebut mengingat program pendidikan sekolah didasarkan atas fakta dan realita, bukan atas keinginan menjadi kaum 
pemodal dengan proses pendidikan yang didasarkan kemodalan. Tan Malaka mengambil prinsip kerakyatan sebagai landasan filosofis dalam praksis pendidikan. Sekiranya dunia memiliki Paulo Freire dalam kecondongan pedagogik kritis serta pendidikan untuk kaum tertindas. Maka Indonesia punya Tan Malaka sebagai "pendidik massa" kaum ploretar dan kromo Indonesia.

\section{Prinsip Pendidikan}

Prinsip yang dipakai dalam pendidikan Tan Malaka ialah semangat antikolonialisme. Marxisme-Lenisme menjadi nalar kritisnya. Inilah yang disebut pendidikan transformatif di mana ia berupaya untuk mencari jalan hidup di tengah kemelaratan, kegelapan, serta kelaliman dan perbudakan (Malaka, 2011, hal. 15).

Prinsip pendidikan yang digagas Tan Malaka berdasarkan atas fakta dan realita. Menurut Tan Malaka pendidikan tidak dapat terpisah dari mempelajari hakekat realita yang merupakan pusat dari setiap konsep pendidikan. Berlainan dengan proses pendidikan kaum pemodal yang berdasarkan atas kemodalan, Tan Malaka mengambil prinsip kerakyatan sebagai landasan filosofis dalam praksis pendidikanya (Malaka, 2011, hal. 4).

Sebagaimana keterangan yang Tan Malaka ungkapkan dalam buku SI Semarang dan Onderwijs. Di mana prinsip pendidikan Tan Malaka berprinsip anti kolonialisme (2011, hal. 4).

\section{Materi Pendidikan}

Dalam pembuatan materi pendidikan Tan Malaka berpendapat bahwa materi pendidikan harus disesuaikan dengan realita yang terjadi di masyarakat dan berpedoman pada kebutuhan masyarakat, baru kemudian menyusunnya menjadi sebuah kurikulum agar materi benarbenar tercapai pada tujuan yang diinginkan (Malaka, 2011, hal. 15).

Hal ini sejalan dengan Mujib bahwa dalam mengimplikasikan materi ke dalam kurikulum haruslah luwes, sehingga mampu disesuikan dengan situasi setempat, waktu dan kondisi yang berkembang, tanpa mengubah tujuan pendidikan yang diinginkan (Umar, 2010, hal. 168).

Sedangkan Ahmad Tafsir berpendapat bahwa isi (materi) dari kurikulum dalam proses belajar-mengajar harus relevan dengan tujuan pengajaran. Misalnya tujuan pengajaran agar siswa dapat menendang bola dengan benar, tentu isi proses belajar-mengajarnya adalah hal menendang bola; bila tujuan yang hendak dicapai adalah agar siswa memahami arti surat al-Fatihah, maka isi proses tentulah terjemahan surat alFatihah (Tafsir, 2012, hal. 83).

Maka sesuailah apa yang dikatakan oleh Mujib dan Ahmad Tafsir bahwa untuk merencanakan kurikulum harus disesuikan dengan tujuan pegajaran. Begitupun dengan Tan Malaka yang mempertimbangkan realita dan kebutuhan masyarakat untuk menyusun materi pendidikan.

\section{Metode Pendidikan}

Metode yang digunakan oleh Tan Malaka dalam pendidikannya ditemukan melalui cara Tan Malaka dalam menulis dan menginterpretasi suatu permasala-han, yang kemudian dapat dikatakan penjembatan antara guru dengan murid, sebagai berikut: 
1) Metode Dialogis, digunakan Tan Malaka agar terjadi dialektika dan tidak membosankan. Dengan menerapkan metode dialog, Tan Malaka dapat mengetahui secara mendetail keadaan siswa, karena baginya, dengan mengajak murid berdialog akan menempatkan murid sebagai seorang teman. Juga dapat membenahi pengetahuan ketika dialog berlangsung. Dialog yang dipakai Tan Malaka ini sebagai upaya untuk mendapatkan berita atau kabar dari yang diajak dialog. Ini dipraktekkannya ketika Tan Malaka menjadi guru di Sekolah Perkebunan Senembah Mij, Tanjung Morawa Deli. Seusai Tan Malaka mengajar, ia selalu mengajak murid-muridnya berdialog, seolah bagaikan seorang teman. Dan dari situlah Tan Malaka menemukan persoalanpersoalan dehumanisasi.

\section{2) Metode Jembatan Keledai} (Ezelbruggeetje), menurut Tan Malaka yang dikutip oleh Afandi \& Rahman (2015, hal. 13) adalah sebuah metode untuk mengingat isi buku, yang dalam penerapanya meringkas sebuah pemahaman akan buku dengan singkatan, tanpa harus menghafal. Metode ini pada mulanya adalah sebuah usaha Tan Malaka untuk memudahkan dirinya dalam menghafal. Pada masa Tan Malaka masih kecil, ia sering mendapatkan pelajaran bahasa Arab dan bahasa Belanda, yang isinya menghafal (Malaka, 2014, hal. 23). Namun ketika beranjak dewasa, ia menemukan bahwa kebiasaan menghafal tidaklah terlalu signifikan menambah kecerdasan, malah menjadikan seperti mesin. Karena menurutnya, yang diingat bukan lagi arti dan makna yang terkandung, melainkan bunyi atau halaman buku dimana kalimat tadi tertulis (Malaka, 2014, hal. 23). Meskipun demikian, Tan Malaka tetap memahami begitu bergunanya pengetahuan yang ada dalam otak maka ia mengambil jalan tegah, yaitu memadukan antara keduanya. Ezelbruggetje, atau Jembatan Keledai adalah jalan tengah. sebagaimana penuturanya dalam buku Madilog (Malaka, 2014, hal. 24).

3) Metode Analogi, Tan Malaka menggunakan metode analogi (perumpamaan) untuk memudahkan murid memahami materi yang disampaikan. Biasanya ia menggunakan perumpamaan dengan benda atau sesuatu yang mudah ditemui oleh murid. Tan Malaka memberikan perumpamaan sebuah klub sepak bola dalam memahami filsafat (Malaka, 2014, hal. 51). Dalam memahami filsafat, bagi Tan Malaka harus terlebih dahulu memisahakan arah pikiran para ahli filsafat agar tidak mengalami kebingungan. Makanya ia mencoba menggungakan perumpamaan sebuah klub sepak bola. Apabila menonton sepak bola, kita harus memisahkan para pemain, mana yang masuk klub A, dan mana yang masuk klub B. Karena kalau tidak begitu, bingunglah orang 
yang menonton pertandingan, karena mana yang menang dan mana yang kalah. Mana yang baik permainannya dan mana yang jelek (Malaka, 2014, hal. 51). Metode analogi juga digunakan Tan Malaka untuk menyampaikan sesuatu pembahasan yang amat sulit dipahami oleh rakyat atau kaum kromo pada masa itu, seperti konsep negara, konsep ekonomi, konsep militer, sampai politik Indonesia mencapai kemerdekaan. Dikemas dalam sebuah cerita yang menarik, agar secara optimal informasi yang disampaikan dapat ditangkap oleh pembaca dan sekaligus menghidur (Poeze H. A., 2008, hal. 192).

Jadi, dapat disimpulkan bahwa metode pendidikan yang dipakai Tan Malaka dalam praksis pendidikanya, yaitu (1) Metode Dialogis, (2). Metode Jembatan Keledai (Ezelbruggeetje), dan (3). Metode Analogi (Perumpamaan).

\section{Evaluasi Pendidikan}

Dalam melakukan evaluasi, Tan Malaka tidak pernah secara formal menyelenggrakannya. Namun ia beranggapan bahwa pendidikan yang ia ajarkan, guru adalah seorang pembimbing, dia bagaikan seorang teman untuk berdialog. Sehingga muridmurid diberi kebebasan dalam mengembangkan semua kemampuan yang ada pada diri mereka masingmasing.

Meskipun demikian, secara normatif konsep pendidikan Tan Malaka menekankan pada aspek afektif. Jadi dalam mengevaluasi, cukup dengan hasil dari proses pendidikan. Juga ada beberapa murid yang di evaluasi dalam bentuk praktik mengajar, hal ini dilakukan agar kelak ia dapat disalurkan untuk mengajar di sekolahan.

Tan Malaka juga selalu mengawasi murid-muridnya yang ingin melanjutkan ke sekolah Belanda, dia memberikan pendampingan agar muridnya tersebut dapat mengerjakan ujian masuk.

"... anak-anak keluaran SI school, yang mau meneruskan pengajaran pada ambachtschool Gouvernement dan sebagainya, tentu dari pibak kita tak akan dapat halangan. Melainkan kita akan menjaga, supaya ia sanggup membuat examen (ujian)..."(Malaka, 2011, hal. 37).

\section{b. Relevansi dengan Pendidikan Islam}

\section{Relevansi Filosofis Pendidikan}

Menurut Zuhairi perkembangan filsafat (pemikiran falsafati) dalam dunia Islam, telah menghasilkan berbagai macam alternatif jawaban terhadap berbagai macam pertanyaan-pertanyaan hakiki problema hidup dan kehidupan manusia. Zuhairi menekankan pentingnya berfikir secara kritis dan radikal tentang hidup dan manusia sebagai khalifah (Zuhairini, 2008, hal. 126).

Lebih lanjut menurut Zuhairi, untuk dapat mendidik diri sendiri, pertamatama manusia harus memahami dirinya sendiri. Apa hakikat manusia, bagaimana hakikat hidup dan kehidupanya. Apa tujuan hidupnya dan apa pula tugas hidupnya. Dalam hal ini membuktikan bahwa manusia berhadapan dengan alam dan lingkungannya, dan manusia harus pula memahami, bagaimana hubunganya 
dengan alam dan lingkungan. Manusia hidup dalam masyarakatnya, di mana ia harus menyesuaikan diri di dalamnya. Manusia hidup bersama dengan hasil cipta rasa dan karsanya (kebudayaannya). Manusia hidup bersama keyakinan dan kepercayaanya, dengan pengalaman pengetahuan yang diperolehnya dalam proses hidupnya (Zuhairini, 2008, hal. 125).

Dengan demikian tinjauan filosofis pendidikan Islam sangatlah menekankan untuk berfikir secara kritis dan radikal terhadap problema hidup, yang kemudian diterapkan pada pendidikan Islam itu sendiri. Setelah memahami hakikat manusia, hidup, alam, masyarakat sampai pada sang pencipta Allah swt.

Sabagaimana pemaparan di atas, pemikiran pendidikan Tan Malaka sejalan dengan pendidikan Islam.

Pertama, walaupun Tan Malaka bersinggungan keras dengan pemikiran Karl Marx, Friedrich Engels, G.W.F Hegel, bahkan terjun ke dunia Partai Komunis Indonesia, namun Islam yang sejak kecil ia percayai tetap menjadi benteng kokoh untuk mempertahankan keislamanya dari lingkungan di mana Tan Malaka tinggal. Karena seperti yang telah diakuinya, bahwa Islam yang ada dalam subconsciousness (alam bawah dasar) selalu membangun kembali ingatanya tentang Islam.

Kedua, menurut Tan Malaka agama Islam adalah agama yang konsekuen dan konsisten memperjuangkan keesaan Allah yang secara jelas tersurat dalam alQur'an surat al-Ikhlas pada ayat pertama. "itulah maka saya anggap bahwa Agama Monotheisme Nabi Mubammad yang paling consequent terus lurus. Maka itulab sebabnya menurut logika maka Mubammad yang terbesar diantara nabinya monotheisme (Malaka, 2014, hal. 25). Selanjutnya dalam bukunya Islam dalam Madilog, Tan Malaka mengatakan bahwa seseorang yang konsisten dan konsekuen mengesakan Tuhan, pasti orang itu mengesakan kekuasaan Allah.

Ketiga, bagi Tan Malaka, agama Islam merupakan agama yang menentang kasta, mengajarkan tentang persamaan manusia dihadapan Tuhan, dan memerangi penindasan terhadap orang miskin. Sehingga inilah yang dijadikan pijakan Tan Malaka dalam mengkonsep pendidikan kerakyatanya, dengan memerdekakan orang-orang yang tertindas, dan mengajarkan kepada murid-muridnya untuk berpikir kritis dalam segala persoalan. Karena cara berpikir yang Tan Malaka gunakan ialah cara berpikir Madilog atau cara berpikir yang berdasarkan materialisme, dialektika dan logikanya untuk mencari akibat yang berdiri atas bukti yang cukup banyak dan cukup dalam untuk diamati. Dan dari Islamlah Tan Malaka mengambil semangat modernisme yang dinamis, mendorong pencapaian kemajuan, dan anti dogmatis (Malaka, 2014, hal. 512)

Dengan demikian melalui tinjauan filosofis, pemikiran pendidikan Tan Malaka sejalan dengan filosofis pendidikan Islam, yang berdasarkan pada sumber Islam.

\section{Relevansi Dasar Pendidikan}

Menurut Ahmadi, dasar pendidikan Islam ialah tauhid atau lengkapnya iman tauhid (pengakuan keesaan Allah). Pandangan hidup tauhid bukan sekedar pengakuan akan keesaan Allah, tetapi juga meyakini kesatuan penciptaan (unity of creation), kesatuan kemanusiaan (unity of 
mankind), kesatuan tuntunan hidup (unity of guidance), dan kesatuan tujuan dari kesatuan ketuhanan (unity of Godhead). Bila pengertian ini ditarik dalam kehidupan sosial, maka tauhid tidak mengakui adanya kontradiksi-kontradiksi berdasarkan kelas, keturunan dan latar belakang geografis. Dan tauhid merupakan dasar Islam menghapuskan disparitas ekonomis, etnis, ras, dan status sosial. Karena dalam Islam didasarkan pada tingkat ketaqwaan, yaitu sejauh mana manusia dapat mewujudkan kehendak Tuhan di muka bumi (Achmadi, 2008, hal. 84).

Adapun dasar-dasar lainnya dalam pendidikan Islam hanya merupakan penjabaran dari dasar tauhid. Yaitu (1). Kemanusiaan, implikasi terhadap pendidikan adalah persamaan dalam pendidikan, dan harus memperlakukan manusia sebagai manusia bukan sebagai mesin. (2). Kesatuan umat manusia seperti kesejahteraan, keselamatan dan keamanan manusia. (3). keseimbangan keadilan objektifitas sebagai pendidik, (4). Rahmatan lil al 'alamin atau kedamaian dunia (Achmadi, 2008, hal. 85-90).

Keempat dasar lain dalam pendidikan Islam di atas menurut Achmadi merupakan penjabaran atau konsekuensi dari tauhid. Maka implikasinya adalah dalam menyusun konsep pendidikan Islam yang komprehensif lebih tepat menggunakan pendekatan sistem atau melibatkan semua bidang kehidupan sebagai instrumental dan input (Achmadi, 2008, hal. 85-90).

Dengan demikian bahwa dasar pendidikan Islam sudah cukup dengan Tauhid karena merupakan sumber paling tinggi atau fundamental. Kemudian untuk penjabaran atau konsekuensi dari tauhid, maka diperlukan dasar pendidikan Islam yang komprehensif, mencakup nilai kemanusiaan, kesatuan umat manusia, keseimbangan, dan Rabmatan Li al-alamin.

Dapat dikatakan bahwa dasar pendidikan Tan Malaka sejalan dengan dasar pendidikan Islam sebagai penjabaran atau konsekwensi dari tauhid.

Pertama, bagi Tan Malaka, manusia merupakan makhluk yang dapat mengetahui realitas yang sebenarnya dan dengan ilmu pengetahuan, manusia dapat merdeka dan mengalami kemajuan. Pemikiran pendidikan Tan Malaka juga berusaha untuk membebaskan manusia dari kesengsaraan, ketertindasan, dan kebodohan, menjadikan hidup lebih bermanfaat bagi diri sendiri dan sekitarnya, tidak ada lagi kasta dan pembeda kelas-kelas (Malaka, 2011, hal. 13).

Kedua, Pendidikan kerakyatan Tan Malaka adalah berdasarkan kerakyatan, persamaan terhadap hak-hak rakyat dalam mendapatkan pendidikan yaitu dengan menerima rakyat sebagai murid akibat tidak diperbolehkan sekolah di sekolah Belanda, menghilangkan disparitas ekonomi, etnis, agama, ras dan status sosial (Malaka, 2011, hal. 4).

Ketiga, Tan Malaka mendidik muridmuridnya sesuai dengan apa yang disukai murid, dan memberi materi yang dibutuhkan kelak. Hal ini dilakukan Tan Malaka agar pada nantinya mereka bisa sejahtera, bagi diri sendiri dan masyarakat secara luas (Malaka, 2011, hal. 25).

Keempat, Keseimbangan juga diperhatikan oleh Tan Malaka dalam mendidik, selain menekankan kepada 
murid-muridnya untuk mengoptimalkan potensi yang dimiliki, Tan Malaka juga menekankan kepada murid-murid akan pentingnya kebersihan dan kesehatan. Ini adalah sebuah upaya Tan Malaka dalam menjaga keseimbangan antara jasmani dan rohani (Malaka, 2011, hal. 25).

\section{Relevansi Tujuan Pendidikan}

Achmadi membagi tahapan tujuan pendidikan Islam ke dalam tiga tahapan, (1). Tujuan tertinggi dan terakhir, yaitu ma'rifatullah. (2). Tujuan umum, yaitu bersifat empirik dan realistis, karena dapat diukur dari perubahan sikap dan tingkah laku atau realisasi diri (self realization). (3). Tujuan khusus yang merupakan operasionalisasi tujuan akhir dan tujuan umum. Sedangkan untuk mencapai tujuan akhir pendidikan Islam menurut Achmadi harus mencakup dua hal, (1). Pendidikan memungkinkan manusia mengerti tuhanya secara benar.

(2). Pendidikan harus menggerakkan potensi manusia (SDM) untuk memahami sunnah Allah di atas bumi, mengenalinya, dan memanfaatkanya untuk mewujudkan kemakmuran dan kesejahteraan bersama (Achmadi, 2008, hal. 94-103).

Tujuan pendidikan Islam adalah memahami statusnya sebagai seorang mahluk atau manusia, dan hubungannya dengan mahluk atau manusia lainnya (sosial), serta alam sekitarnya, yang merupakan pengetahuan dan wawasan (kognitif), menyadari tanggung jawab sesuai dengan pemahaman yang dimilikinya (afektif), dan melaksanakan kegiatan (amal) sesuai dengan pemahaman dan kesadaran akan tanggungjawabnya (psikomotor). Dari semua instrumental tersebut merupakan kemampuan yang diperlukan untuk ma'rifatullah dan taat beribadah kepada Allah swt.

Dengan demikian Tujuan Pendidikan Tan Malaka sejalan dengan Tujuan umum dan Terakhir dari Pendidikan Islam.

Pertama, tujuan pendidikan Tan Malaka menekankan kepada pengenalan terhadap diri pribadi, strating point yang dilakukanya adalah dengan memberikan bahan pengetahuan yang sebanyakbanyaknya seperti berhitung, bahasa, sejarah, dan sebagainya dengan tujuan agar murid mendapatkan banyak bekal setelah mereka besar. Tan Malaka juga menggali potensi yang dimiliki para murid dan setelah itu ditumbuh kembangkannya. Tujuan Tan Malaka ini untuk mengarahkan murid-murid agar dapat mengerti tentang hakikat Sang Pencipta yaitu Allah swt. Karena dalam hadis nabi Muhammad Saw, pula telah jelas bahwa barang siapa mengenali dirinya, maka dia akan mengenali Tuhanya (Allah swt).

Hamdani Ihsan dan Fuad Ihsan menjelaskan tentang cara bagaimana manusia mengenali diri sendiri, yakni dapat dilakukan dengan cara membaca, sesuai dengan al-Qur'an surat al-Alaq ayat 1-5. membaca yang dimaksudkan bukan hanya dalam teks atau yang tertulis, tetapi juga membaca kemampuan diri sendiri, alam sekitar, serta latar belakang dari kedua itu (metafisika). Jadi yang dikehendaki oleh Allah ialah agar manusia mampu membaca apa yang tersurat dan tersirat, sehingga mengenali dirinya dan bertindak sesuai dengan pengenalanya (Ihsan \& Ihsan, 2007, hal. 23-24). 
Kedua, tujuan Tan Malaka mendidik murinya untuk mengenali dirinya dan mengembangkan potensi-potensi yang dimilikinya, selanjutnya Tan Malaka juga mengenalkan mereka dengan lingkungan dan alam sekitarnya, mereka dikenalkan dengan rakyat Indonesia yang masih tertindas dan terjajah oleh kekejaman Belanda. Mereka diajarkan bagaimana memanfaatkan alam dengan kemampuan yang dimiliki. Sebetulnya hal ini dilakukan Tan Malaka agar murid menyadari tanggung jawab yang mereka emban ketika nanti telah lulus dari sekolah, sehingga ketika nanti bertumbuh pola pendidikan ini yang menjadi watak dalam dasar pergerakan murid dengan segala kemampuan yang murid miliki.

Sejalan dengan tujuan pendidikan Islam, menurut Achmadi (1). Mengembangkan wawasan subjek didik mengenai dirinya dan alam sekitarnya, sehingga dengannya akan timbul kemampuan membaca (analisis), akan mengembangkan kreativitas dan produktivitas, (2). Melestarikan nilai-nilai insani yang akan yang akan menuntun jalan kehidupanya sehingga keberadaanya, baik secara individu maupun sosial, lebih bermakna, (3). Membuka pintu ilmu pengetahuan dan keterampilan yang sangat bermanfaat bagi kelangsungan dan kemajuan hidup individu maupun sosial.

\section{KESIMPULAN}

Tan Malaka merupakan tokoh pejuang yang militan, radikal, dan revolusioner yang melahirkan pemikiran-pemikiran yang orisinil, berbobot, dan brilian sehingga berperan besar dalam sejarah perjuangan kemerdekaan Indonesia.

Bagi Tan Malaka pendidikan adalah sebuah usaha untuk membebaskan manusia dari kesengsaraan, ketertindasan, dan ketidaktahuan, menjadikan hidup lebih bermanfaat bagi diri sendiri dan sekitarnya, tidak ada lagi kasta dan pembeda kelas-kelas..

Untuk merumuskan tujuan pendidikanya, Tan Malaka menyesuaikan dengan realitas atau kebutuhan masyarakat pada waktu itu, yaitu (1). Memberi keterampilan, (2). Memberi keleluasaan terhadap potensi belajarnya, termasuk kesukaan hidup (hobi), dengan jalan bergaul atau berkumpul, (3). Menanamkan rasa peduli dan tolong menolong terhadap sesamanya. Prinsipnya atas fakta dan realita, sehingga mampu menstransformasikan pengetahuan sebagai upaya untuk mencari jalan hidup. Basis pergerakan rakyat dan semangat anti-kolonialisme. Materi ajarpun disesuaikan dengan keahlian peserta didik. Dialog, Jembatan Keledai (Ezelbruggeetje), dan Analogi sebagai metode pendidikanya. Evaluasi secara praktif tanpa tes formal, ketika murid telah mampu mengajar sesamanya sebagai bahan evaluasi, bahwa pendidikan Tan Malaka memiliki kebermanfaatan.

Relevansinya dari tinjauan filosofis yaitu pada pengakuan Tan Malaka tentang Islam sumber hidup dalam dirinya, pengakuan Tan Malaka yang menentang kasta, mengajarkan tentang persamaan manusia dan memerangi penindasan terhadap orang miskin.

Relevansi dasar dari pendidikan Tan Malaka tercemin dalam tujuan pendidikanya, yaitu (1). Penghargaan atas 
hak manusia dalam memperoleh pendidikan, (2). memperjuangkan persamaan, (3). menghilangkan kasta pembeda (4). meningkatkan sumber daya manusia untuk meningkatkan kesejahteraan. Dalam pendidikan Islam, hal tersebut merupakan penjabaran dari dasar tauhid, yaitu (1). Kemanusiaan, implikasi terhadap pendidikan adalah persamaan dalam pendidikan,. (2). Kesatuan umat manusia seperti kesejahteraan, keselamatan dan keamanan manusia. (3). Keseimbangan keadilan objektifitas sebagai pendidik, (4). Rahmatan lil al 'alamin atau kedamaian dunia.

Relevansi tujuan dari pendidikan Tan Malaka, yaitu (1). Memberi materi pelajaran yang cukup, agar dapat dipergunakan bekal dalam kehidupanya terlebih menghadapi dunia kemodalan, (2). Memberikan sepenuhnya hak-haknya murid, yaitu tentang kegemaran atau kesukaan hidup (hobi), dengan jalan pergaulan atau perkumpulan (vareeniging), (3). Menunjukkan kewajibannya kelak setelah selesai, yaitu berkewajiban menolong sesama rakyat, terutama terhadap rakyat miskin yang teraniaya dan tertindas. Sejalan dengan tujuan umum pendidikan Islam yaitu bersifat empirik dan realistis diri (self realization).

\section{REFERENSI}

Abidin, N. F. (2016, Agustus 23-24). Membebaskan Kaum Kromo: Pemikiran Pendidikan Tan Malaka. Seminar Nasional 71 Tabun Kemerdekaan Indonesia, Universitas Andalas, hal. 4-9.

Achmadi. (2008). Ideologi Pendidikan Islam. Yogyakarta: Pustaka Pelajar.
Afandi, \& Rahman, M. (2015). Ideologi Pendidikan Tan Malaka : Rekonstruksi Konsep Madilog. Jurnal Profesi Pendidik, 8-15.

Alimin, S. (1973). Capita Selecta. Jakarta: Bulan Bintang.

Asy'ari, M. (2004). Kemerdekaan dan Pendidikan. Bandung: Koran Kompas.

Darwis, A. (2014). Metode Penellitian Pendidikan Islam. Jakarta: Raja Grafindo Persada.

Dzulfikriddin, M. (2010). Mohammad Natsir dalam Sejarah Politik. Indonesia : Peran dan Jasa Mohammad Natsir dalam Dua Orde Indonesia. Bandung: PT Mizan Pustaka.

Gandhi, T. (2011). Filsafat Pendidikan : Maz̧hab-Maz̧hab Filsafat Pendidikan. Jogjakarta: Ar-Ruzz Media.

Ihsan, H., \& Ihsan, A. F. (2007). Filsafat Pendidikan Islam. Bandung: Pustaka Setia.

Jalaluddin. (2003). Teologi Pendidikan. Jakarta: PT. Raja Grafindo Persada.

Karim, M. (2009). Pendidikan Kritis Transformatif. Yogyakarta: ArRuzz Media.

Malaka, T. (2011). Serikat Islam Semarang dan Onderwijs. Jakarta: Pustaka Kaji.

Malaka, T. (2014). Islam dalam Madilog. Bandung: Sega Arsy.

Malaka, T. (2014). Madilog. Yogyakarta: Penerbit Narasi.

Malaka, T. (2014). Naar de Republik Indonesia. Bandung: Sega Arsy.

Poeze, H. A. (2008). Tan Malaka, Gerakan Kiri, dan Revolusi Indonesia. Jilid I : Agustus 1945 - 
Maret 1946. (H. Setiawan,

Penerj.) Jakarta: Yayasan Obor

Indonesia; KITLV-Jakarta.

Satori, D., \& Komariah, A. (2014).

Metodologi Penelitian Kualitatif.

Bandung: Alfabeta.

Suwarto, W. (1999). Memperkenalkan Tan

Malaka, Pablawan Kemerdekaan

Nasional Yang Paling. Jakarta:

Pusat Data Indikator.

Tafsir, A. (2012). Ilmu Pendidikan Islami.

Bandung: PT Remaja

Rosdakarya.

Umar, B. (2010). Ilmu Pendidikan Islam. Jakarta: Amzah.

Waini Rasyidin, dkk. (2013). Landasan

Pendidikan. Bandung: Sub

Koordinator MKDP FIP UPI.

Zuhairini. (2008). Filsafat Pendidikan

Islam. Jakarta: Bumi Aksara. 